\title{
SECULAR TRENDS AND LATITUDE GRADIENTS IN THE MALE-FEMALE RATIO AT BIRTH IN YUGOSLAVIA AND THE EX-YUGOSLAVIAN STATES
}

\author{
Victor Grech
}

Department of Paediatrics, Mater Dei Hospital, Malta

\begin{abstract}
Summary: Background: Latitude gradients and secular trends in Europe and North America have been found in the male-female ratio at birth (M/F: male births divided by total births) which approximates 0.515 . Methods: Annual national data for Yugoslavia and the post-Yugoslavia States for male and female live births were obtained from the World Health Organisation and analysed with contingency tables. Results: This study analysed 22,020,729 live births. There was a increasing trend in M/F prior to the breakup of the former Yugoslavia $(1950-1990, p=0.002)$, followed by a decreasing trend after $1990(\mathrm{p}=0.02)$. A latitude gradient was also noted, with more males being born in southern, warmer latitudes $(\mathrm{p}<0.0001)$. There was an overall excess of 42,753 male births based on an anticipated $\mathrm{M} / \mathrm{F}$ of 0.515 . Conclusion: $\mathrm{M} / \mathrm{F}$ is decreasing in this region, similar to the rest of Europe and North America. A latitude gradient is also present with more males being born in warmer (more Southern) latitudes $(p<0.0001)$, even in this small region and over the short timeframe studied.
\end{abstract}

Key words: Asia; Southeastern; Far East; Birth Rate/*trends; Infant; Newborn; Sex Ratio

\section{What is already known on this subject?}

- Latitude gradients have been found in the male-female ratio at birth (M/F: male births divided by total births) which is expected to be 0.515 .

- M/F is declining in North America and the Europe.

- Moreover it had been shown that there is a higher incidence of male births in southern Europe than in the north, with the opposite found in North America.

\section{What this study adds?}

- The post-Yugoslavia States display an overall decreasing trend in $\mathrm{M} / \mathrm{F}$ akin to the rest of Europe and North America.

- However, a male surplus in excess of 0.515 is evident, resulting in an excess of 42,753 male births for the period 1991-2004.

- A latitude gradient is also present with more males being born in warmer (more Southern) latitudes $(p<0.0001)$, even in this small region and over the short period studied.

\section{Introduction}

Gender is determined at conception in mammals, and male births occur slightly in excess (1). The male to female ratio of live births is expressed as the ratio of male live births divided by total live births $(\mathrm{M} / \mathrm{F})$, and for humans, this approximates $0.515(2)$. The reason for this discrepancy is uncertain but a plethora of factors have been proposed (3).
This ratio has recently gathered importance. Since male foetuses are spontaneously aborted more readily than female foetuses under stressful circumstances, $\mathrm{M} / \mathrm{F}$ has been mooted as a potential sentinel health indicator (4).

\section{Latitude variation in $M / F$}

$\mathrm{M} / \mathrm{F}$ varies in geographical space, with a latitude gradient that is different in Europe and North America. More males are born towards the south of Europe, in contrast with the North American continent where more males are born towards the north of that continent $(5,6)$.

\section{Secular variation in $M / F$}

Several studies have also been shown that $\mathrm{M} / \mathrm{F}$ varies in temporal fashion, mostly declining in the above two continents (7).

\section{Yugoslavia ("Land of the Slavs")}

The term "Yugoslavia" embodied the union of six South Slavic nations: Serbs, Croats, Slovenes, Bosniaks, Montenegrins and Macedonians, and was originally formed as a Kingdom in 1918. After the Second World War, this nation became the Socialist Federal Republic of Yugoslavia (SFRY), and was comprised of six socialist states: Bosnia and Herzegovina, Croatia, Macedonia, Montenegro, Serbia, and Slovenia. This second Yugoslavia ended with the dec- 
laration of independence of Croatia, Slovenia and Macedonia in 1991 and Bosnia and Herzegovina's declaration of independence in 1992. This resulted in the Yugoslav Wars between 1991 to 1995 and 1998 to 2001 between secessionist states and the central government in Belgrade. The wars were characterised by harsh, internal ethnic conflicts and caused enormous local economic disruption. Conflicts existed in Slovenia (1991), Croatia (1991-1995), Bosnia (1992-1995) and Kosovo (1998-1999).

This study identifies secular trends in M/F in Yugoslavia and the post-Yugoslavia states from a World Health Organization (WHO) dataset that includes the past sixty years. Trends by geographical latitude are also analysed. The null hypothesis is that there were no significant geographical or secular differences in $\mathrm{M} / \mathrm{F}$.

\section{Methods}

\section{Data sources}

Annual male and female live births were obtained directly from WHO. Data for Bosnia and Herzegovina was unavailable.

\section{Statistics}

Excel was used for data entry, overall analysis and charting. The quadratic equations of Fleiss were used for exact calculation of $95 \%$ confidence intervals for ratios (8). Pearson correlations were calculated in order to ascertain the direction of trend. Chi tests and chi tests for trends for annual male and female births were used throughout.

The latter were applied using the Bio-Med-Stat Excel add-in for contingency tables. This add-in is based on the original work on this subject which led to the development of the Cochran-Armitage test (Dr. Peter Slezák, Institute of Normal and Pathological Physiology, Slovak Academy of Sciences, personal communication).

Latitude trend testing was applied after the post-Yugoslavian states were ranked in the following order (from North to South): Slovenia, Croatia, Serbia and Montenegro, and Macedonia. A p value $\leq 0.05$ was taken to represent a statistically significant result.

\section{Results}

There were 22,020,729 live births available for analysis. Data for the former Yugoslavia was available for 1950-1990. Data for Serbia-Montenegro and Macedonia was only available for 1991-2003 therefore 5-year tables were compiled up to 2004 and calculations for trend were limited to 2003.

\section{Secular trends}

Five year total live births and sex ratios at births, in 5 year intervals, are shown in Table 1 for Yugoslavia and for the post-Yugoslavian states in Table 2. There have been increases and also decreases in $\mathrm{M} / \mathrm{F}$ in different states, but taken individually, these were not significant (Table 3). $\mathrm{M} / \mathrm{F}$ is almost always higher than the anticipated 0.515 . This resulted in an overall excess of 42753 male births for the period 1991-2004.

There was a increasing trend in $\mathrm{M} / \mathrm{F}$ prior to the breakup of the former Yugoslavia (1950-1990, $r=0.4, p=0.002$ - Table 3). After this period, a decreasing trend in $\mathrm{M} / \mathrm{F}$ is manifest for several regions and overall $(\mathrm{r}=-0.5, \mathrm{p}=0.02$ - Table 3).

\section{Latitude gradients}

Slovenia, Croatia, Serbia and Montenegro, and Macedonia exhibit a significant latitude gradient (for the period 1991-2003, latitudes as per Table 3, chi for trend $=28$, $\mathrm{p}<0.0001$ ), with more males being born to the south of the region than to the north.

\section{Discussion}

\section{Secular variation in $M / F$}

Studies which have had access to $\mathrm{M} / \mathrm{F}$ data from before 1950 have described increasing trends in $\mathrm{M} / \mathrm{F}$ prior to this period, followed by a decreasing trend thereafter (9). These trends were especially noticeable in Finland, with a rise in $\mathrm{M} / \mathrm{F}$ between 1751 and 1948, as well as in Denmark (10, 11). Such data was not available for analysis from the WHO data source.

$\mathrm{M} / \mathrm{F}$ has been shown to be declining in Europe and in North America,(7) and the results obtained in this study are in accordance. Moreover, recent work utilising the same WHO dataset has shown the following:

An overall decreasing secular trend in $\mathrm{M} / \mathrm{F}$ was found for Czechoslovakia and the post-Czechoslovakian (Czech Republic and Slovakia) countries $(p<0.0001)$. No latitude gradient was noted (12).

For Scandinavia, a significant decreasing trend in $\mathrm{M} / \mathrm{F}$ was noted in all countries except Norway. There was no latitude gradient (13).

In the British Isles, an overall rise in $\mathrm{M} / \mathrm{F}$ was noted up to the late 1970 s, followed by a decline thereafter. The stepdown between the periods of 1975-1979 to 1980-1984 was highly significant for both northern and southern regions. An overall decreasing trend in $\mathrm{M} / \mathrm{F}$ was noted $(\mathrm{p}=0.04)$ which reversed the expected European latitude gradient. More males are born in Scotland and Northern Ireland than in England and Wales, and the Republic of Ireland $(p=0.02)(14)$.

For Asia, an overall increasing trend in $\mathrm{M} / \mathrm{F}$ was found $(\mathrm{p}<0.0001)$ as well as a latitude gradient, with more males being born in southern, warmer latitudes $(p<0.0001)$. These results are in keeping with European data. The overall $\mathrm{M} / \mathrm{F}$ in Asia may be rising due to improving socioeconomic conditions (15). 
Tab. 1: 5 year total live births and sex ratios at births, in 5 year intervals, for Yugoslavia

\begin{tabular}{|l|l|l|l|l|l|l|l|l|l|}
\hline & $\mathbf{1 9 5 0 - 5 4}$ & $\mathbf{1 9 5 5 - 5 9}$ & $\mathbf{1 9 6 0 - 6 4}$ & $\mathbf{1 9 6 5 - 6 9}$ & $\mathbf{1 9 7 0 - 7 4}$ & $\mathbf{1 9 7 5 - 7 9}$ & $\mathbf{1 9 8 0}-\mathbf{8 4}$ & $\mathbf{1 9 8 5}-\mathbf{8 9}$ & $\mathbf{1 9 9 0}$ \\
\hline $\mathbf{M}$ & 1250519 & 1144097 & 1069218 & 1014277 & 970010 & 996166 & 973146 & 919896 & 173669 \\
\hline $\mathbf{F}$ & 1168118 & 1070908 & 1007161 & 948630 & 907068 & 929062 & 908828 & 858359 & 161483 \\
\hline Tot & 2418637 & 2215005 & 2076379 & 1962907 & 1877078 & 1925228 & 1881974 & 1778255 & 335152 \\
\hline $\mathbf{U C I}$ & 0.51766 & 0.51718 & 0.51562 & 0.51742 & 0.51748 & 0.51813 & 0.51780 & 0.51804 & 0.51987 \\
\hline $\mathbf{M} / \mathbf{F}$ & 0.51703 & 0.51652 & 0.51494 & 0.51672 & 0.51677 & 0.51743 & 0.51709 & 0.51730 & 0.51818 \\
\hline LCI & 0.51640 & 0.51586 & 0.51426 & 0.51602 & 0.51605 & 0.51672 & 0.51637 & 0.51657 & 0.51649 \\
\hline
\end{tabular}

And finally, a study dealing with the South American continent revealed a significant overall increasing trend in $\mathrm{M} / \mathrm{F}$, unlike the decline present in Europe and North America (6). A latitude gradient was also noted with more males being born in cooler (more Southern, $>20^{\circ} \mathrm{S}$ ) latitudes $(\mathrm{p}<0.0001)$, a gradient that is similar to that previously reported for the North American continent and contrary to trends reported in Europe (16).

These shifts are intriguing and it was speculated as early as 1967 that inherent racial differences may influence $\mathrm{M} / \mathrm{F}$ (17). Moreover, $\mathrm{M} / \mathrm{F}$ declines when adverse environmental factors are present. Stressful events encourage females to spontaneously abort male foetuses at higher rates than female foetuses (18). For this reason, M/F has been proposed as a surrogate sentinel health indicator (4).

It has been shown, for example, that $\mathrm{M} / \mathrm{F}$ declines after traumatic events such as after earthquakes (19), and a miscellanea of environmental disasters (20). Contracting economies have also been shown to reduce $\mathrm{M} / \mathrm{F}$ but the overall trends in this paper would not seem to fit this hypothesis (21).

Studies dealing with early periods in German history, such as 1787-1802 (the period of the French Revolutionary Wars), have shown that war and its aftermath may influence M/F (22). Moreover, in Germany, two peaks in M/F have been described in temporal relation to the two World Wars (23), and these peaks were further confirmed by data from the Netherlands (11).

The wartime influence was also shown in Slovenia where it was linked to changes in sperm motility (25). However, Croatian males were shown not to have been affected in this way by the recent strife in the Balkans (25). Moreover, an analysis of the entire region likewise failed to demonstrate any influence on $\mathrm{M} / \mathrm{F}$. However, the authors speculated that a hypothetical threshold or trigger that might involve intensity and/or duration of fighting may have to be reached before $\mathrm{M} / \mathrm{F}$ is affected (26).

James has proposed an M/F cycle that fluctuates over a thirty year period, a homeostatic mechanism that negatively correlates $\mathrm{M} / \mathrm{F}$ with the adult sex ratio at the time of conception (1), but this is not noted in the data.

An increasing maternal age at first pregnancy has also been described in developed countries since the introduction of the oral contraceptive pill in the 1980 s, but this dataset is unable to explicate any such effects (27).
Tab. 2: 5 year total live births and sex ratios at births, in 5 year intervals, for the post-Yugoslavian states

\begin{tabular}{|c|c|c|c|c|}
\hline & & 1991-94 & 1995-99 & 2000-04 \\
\hline \multirow{6}{*}{ Slovenia } & M & 41589 & 46783 & 45269 \\
\hline & $\mathbf{F}$ & 39215 & 43946 & 42624 \\
\hline & Total & 80804 & 90729 & 87893 \\
\hline & UCI & 0.51814 & 0.51889 & 0.51836 \\
\hline & $\mathbf{M} / \mathbf{F}$ & 0.51469 & 0.51563 & 0.51505 \\
\hline & LCI & 0.51124 & 0.51238 & 0.51174 \\
\hline \multirow{6}{*}{ Croatia } & $\mathbf{M}$ & 100871 & 129409 & 105436 \\
\hline & $\mathbf{F}$ & 95047 & 122332 & 99372 \\
\hline & Total & 195918 & 251741 & 204808 \\
\hline & UCI & 0.51708 & 0.51601 & 0.51697 \\
\hline & $\mathbf{M} / \mathbf{F}$ & 0.51486 & 0.51406 & 0.51480 \\
\hline & LCI & 0.51265 & 0.51210 & 0.51264 \\
\hline \multirow{6}{*}{$\begin{array}{l}\text { Serbia } \\
\text { and } \\
\text { Montenegro }\end{array}$} & $\mathbf{M}$ & 218029 & 343889 & 200310 \\
\hline & $\mathbf{F}$ & 201404 & 318123 & 186802 \\
\hline & Total & 419433 & 662012 & 387112 \\
\hline & UCI & 0.52133 & 0.52066 & 0.51902 \\
\hline & $\mathbf{M} / \mathbf{F}$ & 0.51982 & 0.51946 & 0.51745 \\
\hline & LCI & 0.51831 & 0.51826 & 0.51587 \\
\hline \multirow{6}{*}{ Macedonia } & M & 69223 & 77945 & 57462 \\
\hline & $\mathbf{F}$ & 64706 & 71643 & 53628 \\
\hline & Total & 133929 & 149588 & 111090 \\
\hline & UCI & 0.51954 & 0.52360 & 0.52020 \\
\hline & $\mathbf{M} / \mathbf{F}$ & 0.51686 & 0.52106 & 0.51726 \\
\hline & LCI & 0.51418 & 0.51853 & 0.51431 \\
\hline \multirow{6}{*}{$\begin{array}{l}\text { Total } \\
\text { (all four above) } \\
\text { for 1991-94 }\end{array}$} & M & 429712 & 598026 & 408477 \\
\hline & $\mathbf{F}$ & 400372 & 556044 & 382426 \\
\hline & Total & 830084 & 1154070 & 790903 \\
\hline & UCI & 0.51875 & 0.51910 & 0.51757 \\
\hline & $\mathbf{M} / \mathbf{F}$ & 0.51767 & 0.51819 & 0.51647 \\
\hline & LCI & 0.51660 & 0.51728 & 0.51537 \\
\hline
\end{tabular}

Data for Slovenia and Croatia to 2004.

Data for Serbia and Montenegro and Macedonia to 2003. 
Tab. 3: Years available, total male and female live births and chi squared for trend analysis of the annual male to female ratio for Yugoslavia and the post Yugoslavian states

\begin{tabular}{|l|l|l|l|l|l|l|l|}
\hline & Yugoslavia & Slovenia & Croatia & $\begin{array}{l}\text { Serbia and } \\
\text { Montenegro }\end{array}$ & Macedonia & Post-Yugoslavia & All \\
\hline Latitude & $40^{\circ}-47^{\circ}$ & $45^{\circ}-47^{\circ}$ & $42^{\circ}-47^{\circ}$ & $41^{\circ}-47^{\circ}$ & $40^{\circ}-43^{\circ}$ & $40^{\circ}-47^{\circ}$ & $40^{\circ}-47^{\circ}$ \\
\hline Years & $1950-90$ & $1991-2004$ & $1991-2004$ & $1992-2003$ & $1991-2003$ & $1991-2004$ & $1950-2004$ \\
\hline M & 8510998 & 133641 & 335716 & 762228 & 204630 & 1436215 & 9947213 \\
\hline F & 7959617 & 125785 & 316751 & 706329 & 189977 & 1338842 & 9298459 \\
\hline Tot & 16470615 & 259426 & 652467 & 1468557 & 394607 & 2775057 & 19245672 \\
\hline UCI & 0.5170 & 0.5171 & 0.5157 & 0.5198 & 0.5201 & 0.5181 & 0.5171 \\
\hline M/F & 0.5167 & 0.5151 & 0.5145 & 0.5190 & 0.5186 & 0.5175 & 0.5169 \\
\hline LCI & 0.5165 & 0.5132 & 0.5133 & 0.5182 & 0.5170 & 0.5170 & 0.5166 \\
\hline r & 0.4 & -0.1 & -0.5 & -0.6 & -0.6 & -0.5 & 0.3 \\
\hline chi trend & 9 & 0.2 & 7 & 5.4 & 0.1 & 5 & 0.02 \\
\hline p & 0.002 & ns & ns & 0.01 & 0.6 & & 0.0002 \\
\hline
\end{tabular}

Post-Yugoslavia: the aggregate of all countries for the period 1991-2004.

All: 1950-1990 as Yugoslavia, 1991-2004 as the aggregate for the post-Yugoslavian states.

\section{Latitude variation in $M / F$}

$\mathrm{M} / \mathrm{F}$ exhibits a variable latitude gradient. It has been shown that more males are born towards the south of Europe while more males are born toward the north of the North American continent $(5,6)$. At face value, this dataset supports the former (European) latitude gradient at statistically significant levels, with more males born at southern and therefore warmer latitudes. But the entire region extends over just seven degrees of latitude (latitudes as per Table 3), with some degree of overlap of the states being studied, and only spans 14 years with relatively small numbers of live births. However, no reason for this gradient other than latitude is apparent.

In conclusion, significant temporal and geographical $\mathrm{M} / \mathrm{F}$ gradients are observed that defy easy explanation, even over this study's short time span and in this relatively small geographical region.

\section{Acknowledgements}

Mie Inoue and Gauden Galea from the World Health Organisation.

\section{References}

1. James WH. What stabilizes the sex ratio? Ann Hum Genet 1995; 59 (Pt 2): 243 249 .

2. James WH. The human sex ratio. Part 1: A review of the literature. Hum Biol 1987; 59: 721-752.

3. James WH. Evidence that mammalian sex ratios at birth are partially controlled by parental hormone levels around the time of conception. J Endocrinol 2008; 198: 3-15.
4. Davis DL, Gottlieb MB, Stampnitzky JR. Reduced ratio of male to female births in several industrial countries: a sentinel health indicator? JAMA 1998; 279: $1018-23$.

5. Grech V, Vassallo-Agius P, Savona-Ventura C. Declining male births with increasing geographical latitude in Europe. J Epidemiol Community Health 2000; 54: $244-246$.

6. Grech V, Savona-Ventura C, Vassallo-Agius P. Unexplained differences in the sex ratio at birth in Europe and North America. Br Med J 2002; 324: 1010-11.

7. Grech V, Vassallo-Agius P, Savona-Ventura C. Secular trends in sex ratios at birth in North America and Europe over the second half of the 20th century. J Epidemiol Community Health 2003; 57: 612-5.

8. Fleiss JL. Statistical methods for rates and proportions. New York: John Wiley and Sons, 1981: 14-15 (2nd edition).

9. Fellman J, Eriksson AW. Temporal trends in the secondary sex ratio in Nordic countries. Biodemography Soc Biol 2011; 57: 143-54.

10. Møller H. Change in male:female ratio among newborn infants in Denmark. Lancet 1996 ; 348: 828-9.

11. van den Broek JM. Change in male proportion among newborn infants. Lancet 1997; 349(9054): 805

12. Grech V. Secular trends and latitude gradients in sex ratios at birth in Czechoslovakia and the post-Czechoslovakian states. Acta Medica (Hradec Kralove) 2012; 55: $138-41$.

13. Grech V. Sex ratios at birth in Scandinavia over the past sixty years. Scand J Public Health 2012; 40: 761-4.

14. Grech V. Sex ratios at birth in the British Isles over the past sixty years. Eur J Pediatr 2012 Dec 30. [Epub ahead of print]

15. Grech V. Secular trends and latitude gradients in sex ratios at birth in Asia over the past sixty years. Pediatr Int $2013 \mathrm{Feb} 4$. doi: 10.1111/ped.12063. [Epub ahead of print]

16. Grech V. Secular trends in sex ratios at birth in South America over the second half of the 20th century. Jornal de Pediatria - in press.

17. Visaria PM. Sex ratio at birth in territories with a relatively complete registration. Eugen Q 1967; 14: 132-42.

18. Byrne J, Warburton D. Male excess among anatomically normal fetuses in spontaneous abortions. Am J Med Genet 1987; 26: 605-11.

19. Fukuda M, Fukuda K, Shimizu T, Møller H. Decline in sex ratio at birth after Kobe earthquake. Hum Reprod 1998; 13: 2321-2.

20. Lyster WR. Altered sex ratio after the London smog of 1952 and the Brisbane flood of 1965. J Obstet Gynaecol Br Commonw 1974; 81: 626-31.

21. Catalano RA. Sex ratios in the two Germanies: a test of the economic stress hypothesis. Hum Reprod 2003; 18: 1972-1975.

22. Kemkes A. Secondary sex ratio variation during stressful times: the impact of the French revolutionary wars on a German parish (1787-1802). Am J Hum Biol 2006; 18: 806-21. 
23. Bromen $\mathrm{K}$, Jockel $\mathrm{KH}$. Change in male proportion among newborn infants. Lancet 1997; 349: 804-805

4. Zorn B, Sucur V, Stare J, Meden-Vrtovec H. Decline in sex ratio at birth after

10-day war in Slovenia: brief communication. Hum Reprod 2002; 17: 3173-7.

25. Polasek O, Kolcic I, Kolaric B, Rudan I. Sex ratio at birth and war in Croatia (1991-1995). Hum Reprod 2005; 20: 2489-91.
26. Polasek O. Did the 1991-1995 wars in the former Yugoslavia affect sex ratio at birth? Eur J Epidemiol 2006; 21: 61-4.

27. Leader A. Pregnancy and motherhood: the biological clock. Sex Reprod Menopause $2006 ; 4: 3-6$.

Received: 24/09/2012

Accepted in revised form: 07/03/2013

\section{Corresponding author:}

Prof. Victor Grech, Department of Paediatrics, Mater Dei Hospital, Malta; e-mail: victor.e.grech@gov.mt 